\title{
The effect of liquidity risk on the performance of banks: Evidence from Jordan
}

\author{
Mohammed AL-Ardah ${ }^{\mathrm{a}}$ and Saleh K. Al-Okdeh ${ }^{\mathrm{a} *}$
}

${ }^{\text {a Applied Science Private University, Jordan }}$

\begin{tabular}{l}
\hline C H R O N I C L E \\
\hline Article history: \\
Received March 18, 2021 \\
Received in revised format May \\
182021 \\
Accepted June 222021 \\
Available online \\
June 22 2021 \\
\hline Keywords: \\
Liquidity Risk \\
Financial Performance \\
Jordanian commercial banks
\end{tabular}

\section{Introduction}

The banking sector is one of the most vital sectors for its significant role in supporting and stimulating the economy, through its many experiences in implementing the objectives of the State's financial policy, thus increasing its efficiency and effectiveness in attracting deposits and granting loans by providing means of financing through collecting and directing savings to investors, particularly in the form of granting various loans, which are the main tasks of commercial banks, taking into account both profitability and liquidity. Liquidity ratio of banks is considered as is one of the most important indicators for commercial bank administrations to avoid exposure to an increase or decrease in the liquidity ratio, as once there is a lack of liquidity, this may lead to the loss of depositors' confidence and drive them directly to withdraw their deposits,

* Corresponding author.

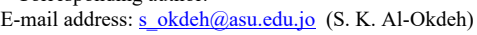

C 2022 Growing Science Ltd. All rights reserved.

doi: $10.5267 /$ j.ac.2021.6.017

\begin{abstract}
A B S T R A C T
study aimed to determine the impact of liquidity risk on financial performance of Jordanian banks, where liquidity risk was measured by (Liquidity ratio, net working capital, cash and investment ratio to total deposits), and financial performance was also measured the natural logarithm of total assets was also added. To achieve the objectives of the study, the analytical quantitative approach was adopted. The study community consisted of all 13 commercial banks listed on the Amman Stock Exchange. All banks in the study community were selected as a study sample using the comprehensive survey method, and the statistical analysis program (SPSS) was used to test the study hypotheses. Based on the results of the statistical analysis, it was found that there was an impact of liquidity risk on financial performance measured by return on assets in Jordanian commercial banks listed on Amman Stock Exchange, and there was an impact for each of (current liquidity ratio, net working capital, cash and investment ratio to total deposits) on financial performance measured by return on assets in Jordanian commercial banks listed on Amman Stock Exchange. It was also found that the size of the bank contributes to modifying the effect of liquidity risk on financial performance measured by return on assets in Jordanian commercial banks listed on Amman Stock Exchange. The study concluded a set of recommendations, the most important of which are: commercial bank administrations should increase interest in exploiting their liquidity within acceptable risk limits to reach optimal ratios for financial performance by balancing the returns to be achieved with the potential risks of such expenses in a way that ensures the positive impact of liquidity risk on the financial performance of those banks.
\end{abstract}


hence, the importance of liquidity management (Bouzida, 2015). The bank's liquidity is one of the most important challenges facing banking activity, where its high levels lead to the problem of low investment in more profitable areas, and its low levels lead to a fundamental problem for commercial banks that they will not be able to meet cash withdrawals by depositors. Banks seek to achieve the objectives that allow them to survive and harmonize profitability and liquidity to ensure their continuity, avoid bankruptcy and achieve the highest possible return, as liquidity plays a significant role in making investment decisions because most investment decisions are related to the available liquidity ratio (Wahdan, 2017). Liquidity generally reflects the ability to convert current assets into cash for the purpose of meeting accrued liabilities. Liquidity can be measured by liquidity ratios, which represent a set of ratios that measure the ability of banks to meet shortterm obligations by providing appropriate liquidity, as liquidity ratios are used as tools to assess an enterprise's credit position which usually reflects the ability of the enterprise to meet its short-term obligations and these ratios include Current ratio, Quick Acid Ratio, and Cash Ratio. Liquidity is a lifeline for all commercial enterprises and banks operating in a constantly changing business environment, where inadequate liquidity or poor cash availability can have a detrimental effect on survival and sustainability, and in order to avoid a liquidity crisis, management needs in particular to define a clear and specific policy that clarifies the procedures for measuring and controlling liquidity management, where the determinants of banks' performance are divided into internal and external factors, internal factors focus on bank-specific characteristics such as bank size and liquidity risk, while external factors include macroeconomic variables which are the gross domestic product and inflation. In this study, the focus will be on liquidity risks and their impact on the financial performance of commercial banks, the most notable of which will be the liquidity ratio, net working capital, cash and investment ratio to total deposits and their impact on return on assets (Al-Farid, 2017). The new liquidity framework developed by the Basel Committee on Banking Supervision (BCBS) contains the Liquidity Coverage Ratio - LCR, which requires all commercial banks to retain enough liquid assets, which enables them to remain 30 days under market pressure, in addition to the appropriate net constant transfer ratio, which are two basic means imposed to measure liquidity (Brah, 2013).

In the light of the above, this study will attempt to find the relationship between a set of liquidity risk indicators and test their impact on the financial performance of Jordanian commercial banks, as well as examining the role played by bank size as measured by the total assets in this relationship.

\subsection{The study problem and research questions}

The liquidity problem in commercial banks may lead to a loss of customers' confidence arising from the poor management of their liquidity, where liquidity is largely concentrated in banks that have the advantage of managing liquidity risk efficiently and effectively, while there will be an inability to provide liquidity in banks that do not focus on financial indicators and cash flow detection as one of the most important analytical tools to help management reduce liquidity risks, take necessary precautions and develop appropriate strategies, as the problem of poor liquidity management and its impact on the banking sector as a whole may arise through the concentration of liquidity in some banks and the inability to employ them to achieve the greatest possible return, as well as the loss of liquidity in other banks leads to their inability to pay short-term obligations and to bankruptcy. The study problem lies in answering the following main question "Do liquidity risks affect the financial performance of Jordanian commercial banks?".

Based on what has been mentioned, this leads us to formulate the study problem in the following sub-questions:

1. Does liquidity risk measured by the current ratio affect the financial performance of commercial banks?

2. Is there an impact of net working capital on the financial performance of commercial banks?

3. Does cash and investment ratio to total deposits affect the financial performance of commercial banks?

4. Do bank size assets affect the relationship between liquidity indicators and financial performance in commercial banks?

\subsection{Importance of the study}

The importance of this study comes as it examines the impact of liquidity risk indicators on the financial performance of commercial banks as they have become increasingly important to many banks, as previous studies have shown that wrong practices in liquidity risk management may lead to loss of customers' confidence in the bank and then to bankruptcy, as a result of inadequate liquidity on demand resulting from a lack of efficient and effective use of available liquidity and vice versa, the Bank may retain more liquidity than it needs resulting in the failure to generate the required return as a result of the lack of efficient and effective use of available liquidity. This study derives its importance from the importance of efficient and highly effective liquidity management and its essential role in enhancing the liquidity and stability of commercial banks and thus their long-term survival and sustainability, as the study with the results to be revealed will generally help commercial bank boards to identify key indicators that are guided in liquidity management in order to maximize their profitability and enhance their sustainability, noting that this study will contribute to assessing the financial performance of banks, which in turn will help regulators to know the situation of these banks and enable them to take action and measures that will help and support the stability of banks and protect them from risk. 
The purpose of this study is to test the impact of liquidity risk management on financial performance of Jordanian commercial banks, as liquidity risk management is one of the most important tools to assess the performance and achieve financial stability of commercial banks in order to achieve the highest possible level of returns and profits, as well as to avoid any adverse effects resulting from poor liquidity risk management through preventive policies and measures taken by commercial banks to avoid liquidity risks. This study seeks to achieve several objectives, including:

- Measuring the impact of liquidity risk management on financial performance of Jordanian commercial banks.

- Knowing the effect of the bank's size measured by total assets on the relationship between indicators of liquidity risks and financial performance of commercial banks listed on Amman Stock Exchange.

\subsection{Study hypotheses}

Based on the questions of the study problem, hypotheses can be formulated as follows:

H1: There is an impact of liquidity management risk (current ratio) on the financial performance (return on assets) of commercial banks.

$\mathbf{H}_{2}$ : There is an impact of liquidity management risk (net working capital) on the financial performance (return on assets) of commercial banks.

$\mathbf{H}_{3}$ : There is an impact of liquidity management risk (cash and investment ratio to total deposits) on the financial performance (return on assets) of commercial banks.

H4: There is an impact of bank size on the relationship between liquidity risk and financial performance.

\section{Theoretical framework and previous studies}

Several studies have discussed the impact of liquidity risk on the financial performance of Jordanian commercial banks which is of great importance to banks, and many researchers believe that it may reflect the strength and continuity of banks' work and success, as efficient and highly effective management of liquidity risk for commercial banks is an important objective of senior management, as it has a significant impact on the performance of commercial banks.

\subsection{Liquidity Risk}

Liquidity means a set of cash flows or funds available to the bank that determine its ability to cope with emergency situations and that require immediate additional funds, where liquidity is the safety valve and the guarantee margin for the bank, as it is one of the most important determinants and thus its ability to obtain additional funds from banks or the Central Bank, moreover, it is one of the key factors in increasing the Bank's ability to obtain additional deposits from workers and attract more savings (Iman, 2017). The financial crisis proved that liquidity risk is an important factor in the banking sector, as it refers to the risk that the bank will not be able to meet the obligations of depositors or finance the increase in assets when due without incurring unacceptable financial costs or losses (Cai \& Zhang, 2017). Hence the importance of liquidity risk management as an effective tool for Jordanian commercial banks, which manage liquidity risks efficiently and effectively, and its role in maintaining solvency.

A. Liquidity Ratio: It is used to measure the ability to pay current debts, reflecting the ability of financial institutions to pay their short-term obligations without any external financial assistance by holding a large proportion of liquid assets. The liquidity ratio also helps to assess the financial situation of companies and financial institutions (Rasham \& Daghim, 2018). Cash liquidity ratio can be calculated through Current Ratio, which is one of the most common financial ratios, is used to measure the ability of commercial banks to pay their short-term obligations in a timely manner and is measured by dividing current assets by current liabilities (Gitman \& Zutter, 2012).

B. Net working capital: It is the surplus of current assets over current liabilities, and it is a measure used in the short term to assess the liquidity of commercial banks and their ability to meet their short-term obligations at the due date, as the greater the amount of current assets compared to current liabilities, the more quantitative evidence that banks can meet short-term obligations easily and vice versa (Al-Armouti, 2017). It can be measured by current assets minus current liabilities.

C. Cash and investment to total deposits ratio (CITDR): It expresses the ability of the cash balance in the fund and the balance of the Central Bank and other local and foreign banks and investments of all kinds to pay the bank's obligations that it must be paid on time, and it shows the high ratio of the cash and investment balance to the ability of financial institutions to meet their obligations on the agreed dates, which means that there is a direct correlation between cash and investment ratio and liquidity ratio (Kazem, 2014). This ratio can be measured by dividing the sum of (cash and investment) by total deposits (Gitman \& Zutter, 2012). 


\subsection{Financial Performance}

Financial performance is one of the most prominent concepts of interest to researchers because of its importance in achieving the main objectives of commercial banks, such as survival and continuity. Financial performance is defined as a reflective mirror of the performance of commercial banks, where it focuses on the use of financial indicators to measure the achievement of objectives and reflects the performance of commercial banks, since it is seen as the primary support for the various business practices of commercial banks, and contributes to providing financial resources and providing banks with investment opportunities in various fields of performance that help meet the needs and objectives of stakeholders (AlArmouti, 2017). The ratio of return on assets (ROA) is one of the most important indicators used to measure financial performance, as this ratio shows the ability of banks to achieve profits because of the use of their assets in their main activity (Agbada \& Osyi, 2013). This ratio can be measured by dividing net profit by total assets (Kabajeh et al., 2012).

\subsection{Previous studies}

Several scientific studies have examined liquidity risks represented by (total cash to total deposits, total loans to total deposits), and financial performance measured by return on assets (ROA) and return on equity (ROE), as the study of (Kaddumia \& Al-Kilani, 2020) to determine the effect of Liquidity Risk Management on the Jordanian Financial Sector, as the success of any financial institution depends mainly on how it forecasts its liquidity needs and that might be through the structure of deposits or the surplus amount that determines performance will be at stake. To achieve the objectives of the study, the analytical descriptive approach was adopted to measure the relationship between Liquidity Risk Management and performance in banks. To analyze this effect, liquidity, and performance indicators of 13 listed Jordanian commercial banks were calculated and analyzed. The study population and its sample consist of the financial data of Jordanian commercial banks. The study indicated that loans to total deposits portrayed a high adverse impact on operating cash flow per share (OCFS) and no effect on earnings per share (EPS). Quick ratio was able to explain a positive change in banking sector performance indicators. Cash and investments to total deposits ratio displayed a positive impact on both performance indicators. Regarding loans to total assets indicator, contemplated a negative low impact on EPS and high negative impact on OCFS. As a conclusion, the impact of liquidity risk management indicators was higher on OCFS than on EPS, thus cash basis performance indicators are more relevant than accrual basis indicators to be employed for liquidity risk management strategy.

The study of (Khalid et al., 2019) aimed at measuring the impact of liquidity risks on the financial performance of commercial banks in developing countries such as Bangladesh during the period from (2010-2017). Total equity to total assets was used as a control variable to demonstrate the relationship between liquidity risk and financial performance. The study was applied to 57 commercial banks listed on Dhaka Stock Exchange during the period from (2010-2017). The results showed that liquidity had no significant impact on return on assets and return on equity as financial performance.

The study of (Altarawneh \& Shafie, 2018) aimed at investigating the impact of operational risk, credit risk, and liquidity risk on bank performance in Jordan. The study utilizes a sample of 15 listed banks in the Amman Stock Exchange (ASE) and the period of study is confined between 2010 and 2014. The dependent variable of the study is bank performance based on Return on Assets (ROA), while risks' variables are operational risk, credit risk, and liquidity risk. The results show that operational and credit risks have a significant negative relationship with ROA while liquidity risk is found to have an insignificant positive relationship with ROA. Also, the study discovers that the relationship between firm size and ROA is negatively significant while the relationship between bank age and ROA is found to be positively significant. Finally, the result of the relationship between management change and ROA is positively insignificant. In addition, the results are important to the practitioners by showing the factors that affect bank performance and enable them to improve their risk management practice. Besides, it also provides valuable information as well as guidance for banking institutions to improve their performance in the future.

The study of (Alqisie, 2018) aimed to explore the role of risk management practices in determining the profitability in (13) Jordanian commercial banks during the period (2010-2015). Data regarding variables were collected from the annual financial statements of the sample study. Return on assets represents the profitability of banks, while risks management practices consist of liquidity, operational, credit and market risks. The study used two ratios to symbolize each type of risk. The ordinary least square method (Fixed effect and Random effect) was used to test the hypothesis. The study revealed that risk management practices explain a significant part of the variation in banks profitability. The results also showed that only operational risk management practices significantly affect the profitability, while liquidity, credit and market risks have insignificant effects. The implications of these results indicated that Jordanian commercial banks (JCB) have successfully managed liquidity, credit, operating income, and market risks during the study period, but at the same time failed to manage operational risk represented in overheads.

The study of (Al-Rdaydeh et al., 2017) aimed at investigating the influence of financial risks on the profitability of banks in Jordan (Islamic and conventional) for the period between 2006 and 2015. Profitability was measured in this study by return on assets (ROA) and return on equity (ROE), while the financial risks were reflected by liquidity and credit risks. The study has employed panel data regression to test the hypotheses. Results illustrated a substantial influence of credit 
risks on both ROA and ROE for the Islamic as well as the conventional banks. The association between liquidity risk and ROE were found to be insignificant for the Islamic and conventional banks. The influence of liquidity risk on ROA is significant for the Islamic and conventional banks. This result gives a clear indication to bank managers and the sector, that undertaking risks funding ventures will result in higher funding losses, with the consequence to banks, of considerable depletion of resources.

The study of (Cai \& Zhang, 2017) aimed at investigating the relationship between liquidity risk measured by (liquidity ratio, efficiency ratio, capital ratio, deposits ratio) and credit risk measured by (return on assets (ROA), return on equity (ROA), loan ratio). To achieve the objectives of the study, the analytical statistical approach was adopted, using a new sample of Ukrainian banks for the period from (2009-2015). The results of the study showed that banks with a high level of nonperforming loans may not meet the requests for withdrawal of depositors, resulting a decrease in cash flow and thus increased liquidity risk.

The study of (Naji \& Hamad, 2017) aimed at investigating the impact of liquidity risk on the profitability of local commercial banks operating in Iraq and measured during the period (2008-2013). Profitability was measured by return on assets (ROA) and return on equity (ROE), and liquidity risk was measured by cash and balances to total assets, and total loans to total deposits. To achieve the objectives of the study, the analytical descriptive approach was adopted to measure the relationship between liquidity risk and profitability. The study was applied to six Iraqi commercial banks during the period (2008-2013). The study found that there is a statistically significant relationship between dependent and independent variables represented by measures of bank liquidity and the profitability of Iraqi commercial banks.

The study of (Samilogu \& Akgun, 2016) aimed at investigating the relationship between working capital management and profitability of 120 industrial companies listed on the Istanbul Stock Exchange for the period from (2003-2013). Profitability was measured by return on assets (ROA), return on equity (ROE), net profit margin (NPM), and operating profit margin (OPM), and working capital management was measured by inventory turnover period (ITP), average receivables collection period (ARP), and average accounts payable repayment period (APP). The multiple linear regression model was used. The study population and its sample consist of the financial data. The study showed that there is a significant and negative relationship between receivables collection period return on assets, operating profit margin, and net profit margin in the manufacturing sector. The researchers expect that managers can create value for shareholders by reducing the receivables collection period, the payable period, and the cash conversion cycle.

\subsection{What distinguishes the study from previous studies}

The current study focuses on liquidity risk management related to indicators of cash liquidity risk with the financial performance of commercial banks and whether the bank size affects the relationship between effective liquidity risk management and profitability indicators. This study was also distinguished from previous studies by the lack of studies on the bank size as a moderating variable and testing a set of liquidity risk indicators which are: the current liquidity ratio, net working capital, and cash and investment to total deposits as independent variables. It should be noted that there are few studies on net working capital among liquidity risk indicators and financial performance as a dependent variable. This study focused on an important and main sector, which is the commercial banking sector in Jordan.

\section{Study methodology}

The study used the analytical quantitative approach in order to demonstrate the impact of liquidity risks on the financial performance of Jordanian commercial banks during the period from (2010-2019), because this approach is one of the most important approaches that are used in humanities and social studies and deal with them to reach data that can be subjected to statistical analysis, in order to test the hypotheses of the study and answer its questions to produce the appropriate results.

\subsection{Study population and sample}

The study community consists of 13 Jordanian commercial banks listed on Amman Stock Exchange as they are at the end of 2019 (www.sdc.com.jo). To obtain expressive and meaningful data, the comprehensive inventory method was used by selecting the banks that have current shares during the study period, and which have all data necessary to calculate the study variables from 2010 to 2019.

Therefore, the study sample consisted of (13) Jordanian commercial banks listed on Amman Stock Exchange, which met the required conditions, representing $100 \%$ of the study population. The study sample is a comprehensive survey of the entire study population, thus enabling the results of the study to be fully generalized to society.

\section{Statistical analysis and hypothesis testing}

This part presents the practical aspect of this study by showing the impact of liquidity risks on the financial performance of commercial banks listed on Amman Stock Exchange, after all data on the study model were collected by analyzing the 
content of the financial statements of Jordanian commercial banks based on multiple linear regression tests and hierarchical regression to reach and discuss the results.

\subsection{Verification of data validity for statistical analysis}

It is important to ensure that the study data follow a set of features before starting the process of multiple regression and hierarchical regression analysis, where independent study variables must be free of linear interference in the presence of the moderating variable to be able to generalize the results, and in the case of one of these problems, the study model must be addressed in order to be able to generalize its results (Ho, 2013; Thompson et al., 2017). The results of the linear interference and self-correlation tests are presented below:

Table 1

Linear interference test and self-correlation

\begin{tabular}{lcc}
\hline Variable & VIF & Tolerance \\
\hline Cash and investment to total deposits & 1.323 & 0.756 \\
Natural logarithm of net working capital & 2.304 & 0.434 \\
Current Liquidity Ratio & 1.660 & 2.170 \\
Bank size & 0.602 & 0.461 \\
\hline
\end{tabular}

The values presented in Table 1 refer to the results of the linear interference test through the variation inflation factor, where the higher value of this indicator than 5 indicates that there is a problem of linear interference between variables that affects generalizing the results of the study model, and the tolerance factor indicates that the variable can remain within the study model if its value is more than $10 \%$ (Thompson et al., 2017). A review of the data presented in the table above shows that the values of these two indicators exceed the recommended values, which indicates that there is no problem of linear interference between the study variables in the study models, where the values of the variance inflation factor ranged between $(1.323-2.304)$, which is within the acceptable range, and the values of the tolerance factor for the study variables ranged between (0.434-0.756), which is also within the acceptable range.

\subsection{Test the descriptive statistics of the study variables}

Based on the data obtained in the financial statements of Jordanian commercial banks that formed the study model, the descriptive statistics of these variables have been tested as follows:

Table 2

Results of the descriptive analysis of the study variables

\begin{tabular}{|c|c|c|c|c|}
\hline Variable & Minimum & Maximum & Mean & Std. deviation \\
\hline Cash and investment to total deposits $\%$ & 41.68 & 85.72 & 59.76 & 9.83 \\
\hline Natural logarithm of net working capital & 17029968 & 6354965000 & 845661671 & 1492384302 \\
\hline Current Liquidity Ratio & 1.01 & 1.91 & 1.22 & 0.13 \\
\hline $\mathrm{ROA} \%$ & 0.05 & 2.51 & 1.21 & 0.48 \\
\hline Bank size & 342656075 & 26328685000 & 4023969450 & 6266353863 \\
\hline
\end{tabular}

Table (2) presents the results of descriptive tests of study variables, and it is noted from the table that the arithmetic mean of return on assets reached (1.21\%), indicating that commercial banks achieve profits on their assets, and the lowest value of return on assets reached $(0.05 \%)$ belonging to the Investment Bank in 2018, where this value indicates that the bank achieved low profits on its assets in that year, while the highest value was $(2.51 \%)$, and this value indicates the bank's ability to generate high profits that on its assets, and the value of the standard deviation was $(0.48)$ due to the differences between the returns achieved by commercial banks. It is also noted that the arithmetic mean of cash and investment ratio to total deposits is $(59.76 \%)$, and the increase in this ratio indicates a decrease in liquidity risk, as its rise reflects the ability and solvency of commercial banks to meet their various obligations, and the value of the standard deviation which is (9.83) indicates a small dispersion in cash and investment ratio to total deposits of Jordanian commercial banks. It is also clear that the arithmetic means of net working capital reached (845661671) which means the average current assets owned by commercial banks after subtracting their current liabilities, and this value indicates the ability of commercial banks to meet their short-term obligations and expand their activities through the proper exploitation of their working capital. The lowest value of net working capital was (17029968), which indicates that the bank had in that year a small surplus of current assets after subtracting current liabilities and thus its ability to pay its debts in the near term, while the highest value was (6354965000), which indicates that in that year the bank had a large surplus of current assets after subtracting current liabilities and thus its ability to pay its debts in the near term, as well as the ability to invest in such assets, and the high value of the standard deviation of (1492384302) justifies differences in the policies followed for the net working capital of Jordanian commercial banks over the study years. It is also noted that the arithmetic means of the current liquidity ratio reached $(121 \%)$, and its rise from 1 indicates that Jordanian commercial banks are prepared to cover their short-term obligations and operating expenses, and the value of the standard deviation which is $(0.13)$ indicates that there is a small 
dispersion in the current liquidity ratio of Jordanian commercial banks. As for the bank size measured by total assets, it is noted that the average size of bank assets which represents the study sample reached $(4,023,969,450)$ Jordanian dinars, and the highest size of assets is $(26,328,685,000)$ Jordanian dinars, while the lowest size of assets is $(342,656,075)$ Jordanian dinars, indicating significant differences in the values of the assets of the study sample banks, which justifies the high standard deviation which reached $(6,266,353,863)$. Therefore, the natural logarithm of the total assets of banks was used to reduce the difference and dispersion in this variable and to match the other variables of the study.

\subsection{Testing the hypotheses of the survey}

\section{The first hypothesis}

Table 3 shows the results of the multiple regression tests of the first main hypothesis and its sub-hypotheses, and it is noted that from the table that the calculated F value reached (8.022), which is significant at a level of (0.05), which indicates that the proposed study model is suitable. The results of the regression analysis also showed that the value of (Sig. F-statistic) which reached (0.000) is less than the significant level of the test, which is $(5 \%)$. Therefore, the first main null hypothesis must be rejected, and the alternative hypothesis is accepted, meaning that there is an impact of liquidity risk on financial performance measured by return on assets in Jordanian commercial banks listed on Amman Stock Exchange.

Table 3

Multiple regression test results

\begin{tabular}{lccc}
\hline Variable & Coefficient $(\beta)$ & Sig. & Std. Error \\
\hline Intercept & - & 0.401 & 0.778 \\
C\&ITOTD & -0.343 & 0.001 & 0.005 \\
NWC & -0.257 & 0.008 & 0.094 \\
CR & -0.267 & 0.009 & 0.382 \\
\hline
\end{tabular}

Adjusted $\mathrm{R}^{2}=0.162 \mathrm{R}^{2}=0.185 \mathrm{R}=0.430 \mathrm{~F}$-statistics $=8.022($ Sig. $=0.000)$

The results of the regression analysis also showed that the value of Adjusted R-square reached (0.162), which means that only about $16.2 \%$ of the fluctuations that occur in the return on assets of Jordanian commercial banks can be explained by the changes that occur in liquidity risk, and this value in this model can be judged as medium in the prediction and interpretation process, but it can be relied upon because it is statistically significant. To determine the impact of each ratio of liquidity risk ratios on financial performance measured by return on assets in Jordanian commercial banks listed on Stock Exchange, the outputs of the multiple regression test were used as follows:

The first sub-hypothesis - Ho1-1: there is no impact of cash and investment ratio to total deposits on financial performance measured by return on assets in Jordanian commercial banks listed on Amman Stock Exchange at a significant level $(\alpha \leq$ $0.05)$.

It is noted from Table 3 that the value of the significant level (Sig.T) decreased from (5\%), where it reached (0.001), and according to the decision rule which states that the null hypothesis is rejected and the alternative hypothesis is accepted if the Sig t value is less than (5\%), thus, cash and investment ratio to total deposits affects return on assets, so the first null sub-hypothesis must be rejected and the alternative hypothesis is accepted, meaning there is an impact of cash and investment ratio to total deposits on financial performance measured by return on assets in Jordanian commercial banks listed on Amman Stock Exchange. According to the Coefficient value which reached (-0.343), it indicates that there is a negative impact of cash and investment ratio to total deposits on financial performance measured by return on assets, and the coefficient value indicates that cash and investment ratio to total deposits is the most influential ratio of liquidity risk on financial performance of Jordanian commercial banks examined in this study.

The second sub-hypothesis - Ho1-2: There is no impact of net working capital on financial performance measured by return on assets in Jordanian commercial banks listed on Amman Stock Exchange at a significant level $(\alpha \leq 0.05)$. It is noted from Table 3 that the value of the significant level (Sig.T) decreased from (5\%), where it reached (0.008), and according to the decision rule which states that the null hypothesis is rejected and the alternative hypothesis is accepted if the Sig t value is less than (5\%), thus, net working capital affects return on assets, so the second null sub-hypothesis must be rejected and the alternative hypothesis is accepted, meaning there is an impact of net working capital on financial performance measured by return on assets in Jordanian commercial banks listed on Amman Stock Exchange. According to the Coefficient value which reached (-0.257), it indicates that there is a negative impact of net working capital on financial performance measured by return on assets, and the coefficient value indicates that net working capital is the lowest ratio of liquidity risk affecting financial performance of Jordanian commercial banks examined in this study.

The third sub-hypothesis - Ho1-1: There is no impact of current liquidity ratio on the financial performance measured by return on assets in Jordanian commercial banks listed on Amman Stock Exchange at a significant level $(\alpha \leq 0.05)$. It is noted from Table 3 that the value of the significant level (Sig.T) decreased from (5\%), where it reached (0.008), and according to the decision rule which states that the null hypothesis is rejected and the alternative hypothesis is accepted if the Sig $t$ value is less than (5\%), thus, the current liquidity ratio affects return on assets, so the third null sub-hypothesis must be rejected 
and the alternative hypothesis is accepted, meaning there is an impact of the current liquidity ratio on financial performance measured by return on assets in Jordanian commercial banks listed on Amman Stock Exchange. According to the Coefficient value which reached (-0.267), it indicates that there is a negative impact of the current liquidity ratio on financial performance measured by return on assets, and the coefficient value indicates that the current liquidity ratio comes in the second place in terms of affecting the financial performance of Jordanian commercial banks examined in this study.

The second hypothesis - $\mathrm{Ho}_{2}$ : the bank size does not contribute to modifying the impact of liquidity risk on financial performance measured by return on assets in Jordanian commercial banks listed on Amman Stock Exchange at a significant level $(\alpha \leq 0.05)$. The impact of liquidity risk on financial performance measured by return on assets in Jordanian commercial banks listed on Amman Stock Exchange has been examined in the existence of the bank size as a moderating variable. Table 4 below shows the results of the multiple hierarchical regression tests:

Table 4

Multiple hierarchical regression test results

\begin{tabular}{lcccc}
\hline Variable & Coefficient $(\beta)$ & Sig. & Std. Error & T-Statistics \\
\hline Intercept & - & 0.686 & 1.135 & 0.4005 \\
C\&ITOTD & -0.395 & 0.000 & 0.133 & -4.054 \\
NWC & -0.541 & 0.000 & 0.423 & -4.210 \\
CR & -0.373 & 0.001 & 0.152 & -3.420 \\
Size & 0.295 & 0.020 & 2.363 \\
\hline
\end{tabular}

First Model: Adjusted $\mathrm{R}^{2}=0.162 \mathrm{R}^{2}=0.185 \mathrm{R}=0.430 \mathrm{~F}$-statistics $=11.0060($ Sig. $=0.000)$

Second Model: Adjusted $\mathrm{R}^{2}=0.261 \mathrm{R}^{2}=0.289 \mathrm{R}=0.538$ F-statistics $=10.071(\mathrm{Sig} .=0.000)$

$\Delta \mathrm{R}^{2}=0.104 \Delta \mathrm{F}=5.585$ Sig. $\Delta \mathrm{F}=0.020$

Table (4) shows the results of the hierarchical regression analysis test for the independent study variable represented by liquidity risk measured by each of (cash and investment ratio to total deposits, the natural logarithm of net working capital, and the current liquidity ratio) combined and its impact on the dependent variable (return on assets as an indicator of financial performance) in the presence of the moderating variable (the bank size) measured by the natural logarithm to the size of assets, as it is noted from the table that the calculated F value reached (10.071), which is significant at a level of (0.05), indicating that the proposed study model is suitable. The results of the hierarchical regression analysis also showed that the value of (Sig. F-statistic) which reached (0.000) is less than the significant level of the test which is (5\%), therefore, the second null sub-hypothesis must be rejected and the alternative hypothesis is accepted, which means that the bank size contributes to modifying the impact of liquidity risk on the financial performance measured by return on assets in Jordanian commercial banks listed on Amman Stock Exchange. It should be noted that the inclusion of the moderating variable in the study model completely changed the level of suitability of the proposed model, as the value of the change between the two models reached $(\Delta F=5.585)$, which is significant at a level of $(0.05)$, where it reached ( $\operatorname{Sig} \Delta F=0.020)$, as well as a significant improvement in the explanatory power of the model after the inclusion of the moderating variable with a value of $\left(\Delta \mathrm{R}_{2}=0.104\right)$, it can therefore be judged that the bank size completely modified the impact of liquidity risk on financial performance measured by return on assets in Jordanian commercial banks listed on Amman Stock Exchange.

The results of the regression analysis also showed that the value of Adjusted R-square reached (0.261), which means that only about $26.1 \%$ of the fluctuations that occur in the financial performance of Jordanian commercial banks measured by return on assets can be explained by the changes that occur in liquidity risk in the presence of moderating variable which is bank size measured by the natural logarithm of assets ratio, and this value in this model can be judged as good in the prediction and interpretation process.

\section{Discussion and recommendations}

\subsection{Results of the study}

After conducting the necessary statistical analysis tests; a series of findings were reached, the most important of which are:

1- There is an impact of liquidity risk on financial performance measured by return on assets in Jordanian commercial banks listed on the Amman Stock Exchange. According to the researchers, this result is logical, as the relationship between risk and return is always strong, so the greater the risk, the greater the expected return and vice versa, which justifies the existence of an impact of liquidity risk on financial performance measured by return on assets. This result is similar to the findings of (Naji \& Hamad, 2017) and (Cai \& Zhang, 2017), while the current result contradicted the findings of the study of (Khalid et al., 2019), which showed that liquidity does not have a significant impact on return on assets as a financial performance, as it was applied to commercial banks in Bangladesh during the period between (2010-2017).

2- The ratio of cash and investment to total deposits has an impact on financial performance measured by return on assets in Jordanian commercial banks listed on the Amman Stock Exchange. It should be noted of the importance of having sufficient cash to cover deposits in banks so that they are not exposed to risk, but on the other hand, the high increase in this ratio may indicate a recession and the failure of the bank to invest adequately in cash and investments available to 
achieve profits. Consequently, the higher this ratio, this indicates low exploitation of cash and investments of the bank, and vice versa, the lower this ratio, this indicates high exploitation of cash and investments of the bank available to achieve profits, which explains the impact of cash and investment ratio to total deposits on financial performance measured by return on assets in Jordanian commercial banks. This result is similar to the findings of (Iman, 2017) and (Cai \& Zhang, 2017), while this result contradicted the findings of the study of (Khalid et al., 2019) which indicated that liquidity has no significant impact on return on assets as a financial performance, as it was applied to commercial banks in Bangladesh during the period between (2010-2017).

3- There is an impact of net working capital on financial performance measured by return on assets in Jordanian commercial banks listed on the Amman Stock Exchange. It should be noted that working capital gives investors an idea about the operational efficiency of the bank, and it is important that the value of net working capital is positive to enable the bank to meet its obligations and debts in the short term, and this may lead to the bank facing the problems of not being able to pay creditors in the short term. The results of the descriptive analysis proved that all sample banks exceeded this problem as all of them maintained that their current assets do not fall below their current liabilities. However, the significant increase in the value of working capital may not be very desirable, as this indicates that the bank has not invested its working capital in an optimal way to achieve profits and make the best use of it, so the higher the working capital than zero, this indicates a lack of optimal utilization of the bank's capital and thus a decrease in profit, which justifies the impact between working capital and financial performance measured by return on assets. This result was similar to the study findings of (Samilogu \& Akgun, 2016) and (Cai \& Zhang, 2017).

4- There is an impact of the current liquidity ratio on financial performance measured by return on assets in Jordanian commercial banks listed on the Amman Stock Exchange. The researchers indicated that the reason for this result is that the greater the liquidity, this indicates a decrease in the bank's exploitation of its assets, and consequently the lower the profits, and vice versa, the less the liquidity, this indicates an increase in the bank's exploitation of its assets, thus generating additional profits, which justifies a negative impact of the current liquidity ratio on financial performance measured by return on assets in Jordanian commercial banks listed on Amman Stock Exchange. This result was similar to the study findings of (Cai \& Zhang, 2017).

5- The bank size contributes to modifying the impact of liquidity risk on financial performance measured by return on assets in Jordanian commercial banks listed on Amman Stock Exchange. The researchers indicated that the reason for this result is the significant variations in the sizes of Jordanian commercial banks, which made the inclusion of the bank size variable measured by assets ratio modifies the impact of liquidity risk on financial performance as the larger the bank size, the greater its ability to invest assets and thereby improve its financial performance. This result is similar to the study findings of (Samilogu \& Akgun, 2016).

\subsection{Study recommendations}

Based on the findings of the study, the study recommends commercial bank administrations to increase interest in exploiting their liquidity within acceptable risk limits to achieve optimal ratios of financial performance by balancing the returns to be achieved with the potential risks of such expenses in a way that ensures the positive impact of liquidity risks on financial performance. Commercial bank managers invest the available liquidity with great caution while financing their clients because poor financing enables increased liquidity risks. Jordanian commercial banks maintain the level of their cash and investments through specialized bodies concerned with risks to determine cash and investments ratio to total deposits, so that they can cover a minimum value of their total deposits to avoid problems of non-fulfilment of obligations if they are due. The need for investors and users of financial statements to pay attention to the size of commercial banks when making their investment decisions in Jordanian commercial banks, as it was found that the bank size works to adjust the relationship between liquidity risk on financial performance in Jordanian commercial banks, as well as its positive impact on improving the level of financial performance of those Banks. Regulators such as Jordan Securities Commission conduct training and awareness courses for investors on the importance of liquidity risk in influencing the financial performance of Jordanian commercial banks. Conducting further studies on liquidity risk management issues facing Jordanian banks, as there are few studies conducted on this topic in Jordan, in order to help decision makers, develop new and improved policies.

\section{References}

Agbada, A., \& Osyi, C. (2013), The Efficacy of Liquidity Management and Banking Performance in Nigeria. International Review of Management and Business Research, 2(1) 223-233.

Al-Armouti, S. (2017), The Impact of Working Capital Management Efficiency on Financial Performance of Industrial Companies Listed on Amman Stock Exchange, Unpublished Master Thesis, Middle East University, Amman-Jordan.

Al-Farid, M. (2017), Liquidity Risk and its Impact on Profitability of Commercial Banks: An Applied Study on a Sample of Commercial Banks in Iraq. The International Journal of Banking and Finance, 16(1) 55-78.

Alqisie, A. (2018) Does Profitability of Jordanian Commercial Banks Get Affected by Risk Management Practices?, European Journal of Scientific Research, 148(3) 319-332.

Al-Rdaydeh, M., Matar, A., \& Alghzwai, O. (2017) Analyzing the Effect of Credit and Liquidity Risks on Profitability of Conventional and Islamic Jordanian Banks, International Journal of Academic Research in Business and Social Sciences, 7(12) 1145-1155. 
Altarawneh, M., \& Shafie, R. (2018) Risks And Bank Performance In Jordan, Academy of Accounting and Financial Studies Journal, 22(6) 1-15.

Bouzida, A. (2015). The Impact of Financial Risks on Financial Performance, Unpublished Master Thesis, Kassdi Merbah University, Ouargla-Algeria.

Brah, H. (2013). Management of Banking Risks according to the Standards of Basel Committee on Banking Supervision, Unpublished Master Thesis, Al-Arabi Bin Mahidi-Oum El Bouaghi University, Algeria.

Cai, R., \& Zhang, M. (2017), How does Credit Risk Influence Liquidity Risk: National bank of Ukrania, Visnyk of the National Bank of Ukraine, 241, 21-33.

Gitman, L., \& Zutter, C. (2012). Principles of Managerial Finance. $13^{\text {th }}$ Ed. Penerbit: Pearson, Boston.

Ho, R. (2013), Handbook of Univar ate and Multivariate Data Analysis with IBM SPSS. $2^{\text {nd }}$ Ed., Chapman and Hall/CRC, New York, USA.

Iman, F., Nurdin, N., \& Azib, A. (2017). The Influence of Liquidity Risk on Banking Performance: Studies in Conventional Commercial Banks Listed on The Indonesia Stock Exchange Period 2011-2015, Presiding Management, 3(1), $135-140$.

Kabajeh, M., Al-Nu'aimat, S., \& Dahmash, F. (2012). The Relationship between the ROA, ROE and ROI Ratios with Jordanian Insurance Public Companies Market Share Prices. International Journal of Humanities and Social Science, 2 (11), 115-120.

Kaddumia, T., Al-Kilani, Q. (2020). The Effect of Liquidity Risk Management on the Jordanian Financial Sector - The Proxy of Commercial Banks. International Journal of Innovation, Creativity and Change, 14(1) 240-253.

Kazem, S. (2014). The Impact of Cash Liquidity on the Level of Banks' Performance: An Analytical Standard Study in Some Iraqi Banks, Unpublished PhD Thesis, St. Clements University, Baghdad, Iraq.

Khalid, M., Rashed, M., \& Hossain, A. (2019). The Impact of Liquidity Risk on Banking Performance: Evidence from the Emerging Market. Global Journal of Management and Business Research, 19(7) 2379-2387.

Naji, K., \& Hamad, A. (2017). Liquidity Risk and its Impact on the profitability of Commercial Banks An Applied Study on a Sample of Commercial Banks in Iraq. Journal of Baghdad College of Economic Sciences, 52, 401-416.

Rasham, M., \& Daghim A. (2018). The Impact of Capital Adequacy According to Basel Committee Requirements on the Profitability of Commercial Banks: An Applied Study on a Sample of Private Iraqi Banks, Al-Muthanna Journal of Administrative and Economic Sciences, 8(1).

Samilogu, F., \& Akgun, A. (2016). the Relationship between Working Capital Management and Profitability: Evidence from Turkey, Business \& Economics Research Journal, 7(2) 1-14.

Thompson, C., Kim, R., Aloe, A., \& Becker, B. (2017). Extracting the Variance Inflation Factor and Other Multicollinearity Diagnostics from Typical Regression Results. Basic and Applied Social Psychology, 39(2) 81-90.

Wahdan, T. (2017). The Impact of Financial Risks on Financial Performance of Commercial Banks, Unpublished Master Thesis, Zarqa Private University, Amman-Jordan.

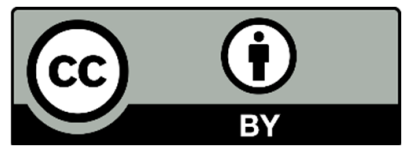

(C) 2022 by the authors; licensee Growing Science, Canada. This is an open access article distributed under the terms and conditions of the Creative Commons Attribution (CC-BY) license (http://creativecommons.org/licenses/by/4.0/). 